\title{
Animal language before Sebeok
}

\author{
Umberto Eco ${ }^{1}$
}

\begin{abstract}
Publication of the text of Umberto Eco's talk given at a symposium held in honour of Thomas A. Sebeok (1920-2001) in San Marino in 2002.
\end{abstract}

Keywords: history of semiotics; zoosemiotics

There is another person who would have been more deservedly entitled than me to open this symposium. Unfortunately this symposium takes place just to remember and honour a dear friend who is no more among us. Tom Sebeok has not been the first to study animal languages but certainly he has been a pioneer in zoosemiotics seen as a branch of semiotics and has devoted a lot of energy and enthusiasm in pursuing this task.

To prove that Tom's research was in a venerable mainstream of philosophical, theological and linguistic speculation, I would like to open our meeting today by recalling some debates about the animal language that took place between the 17th and 18 th centuries.

Animals speak in myths and fairy tales, and such an anthropomorphism was rooted in the everlasting feeling that those impenetrable companions of our life were facing us promising uncanny revelations. The Antiquity was frequently interested in animal sounds: Pliny in his Natural History speaks of the voice of fishes and birds, and Sextus Empiricus deals with the animal logos. He says that we do not understand the voices of animals in the same way we do not understand the voices of barbarians, but this does not exclude that these voices are endowed with some meaning. Dogs emit different sounds in different situations.

1 This is the text of Umberto Eco's talk given at a symposium held in honour of Thomas A. Sebeok in San Marino, 29 June 2002. (A brief account of this event can be found in Kalevi Kull's (2018) article "A study by Umberto Eco and his colleagues on the history of early zoosemiotics: Commentary and bibliography", Sign Systems Studies 46(2/3): 383-391.) Edited and footnotes added by Ene-Reet Soovik and Kalevi Kull. This text is published with the kind permission of Eco's family. 
For centuries, the main argument against animal language was that of Aristotle, who said in Politics (1253a9-10) that "man is the only animal endowed with the gift of speech" because he is the only one to have a rational principle (Politics 1332b5). Men can speak because they are rational. The same point was developed and put upside down by Aquinas in a quaestio which has not been considered enough and where - by accepting the classical definition of man as a rational animal, and considering rationality a differentia specifica - he admitted that we cannot know such a difference directly, if not by means, as we would say today, of behavioural proof. Men prove to be rational because they express their ratio by speaking (Summa Th. I, 29, 2 ad 3; I, 77, 1 ad 7).

This does not mean that the Schoolmen were uninterested in some forms of animal language: in 1985 I published a study with Costantino Marmo, Roberto Lambertini and Andrea Tabarroni on latratus canis in which we showed that many thinkers, from Augustine to Roger Bacon, had reflected on the different ways in which animals not only communicate with us but also communicate with each other. ${ }^{2}$ As Augustine said in De doctrina christiana II, 1.3, "habent enim bestiae quaedam inter se signa, quibus produnt appetitum animis sui. Nam et gallus gallineaceus reperto cibo dat signum vocis gallinae, ut accurrat; et columba gemitu columbam vocat, vel ab ea vicissim vocatur". ${ }^{3}$

Moreover, neither Aristotle nor the Schoolmen denied that animals have a soul. They had, along with a vegetative soul, a sensitive one. Simply they had no rational soul, and that is why their soul is not immortal.

But it was only in the middle of the 17th century that we can see interesting examples of a more empirical approach. In 1650 Athanasius Kircher in his Musurgia Universalis was interested in the sounds emitted by cows, dogs, horses, elephants, lions, bears, and carefully examined the syntax, if not the semantics, of American apes, of cicadas, crickets, frogs and of various sorts of birds. He was, at least, a pioneer in bird watching.

2 Eco, Umberto; Lambertini, Roberto; Marmo, Costantino; Tabarroni, Andrea 1985. Latratus canis. In: L'uomo di fronte al mondo animale nellalto medioevo: 7-13 aprile 1983. Tomo secondo. (Settimane di studio del Centro italiano di studi sull'alto medioevo 31.) Spoleto: Presso la Sede Centro, 1181-1230.

3 "The beasts, too, have certain signs among themselves by which they make known the desires in their mind. For when the poultry-cock has discovered food, he signals with his voice for the hen to run to him, and the dove by cooing calls his mate, or is called by her in turn; [and many signs of the same kind are matters of common observation]." Trans. by J. F. Shaw. See also: Eco, Umberto 2014. From the Tree to the Labyrinth: Historical Studies on the Sign and Interpretation. Cambridge: Harvard University Press, 196-197. 
At the same times, Descartes followed Aristotle in declaring that animals have no language (see for instance his letter to Henry More or Morus, 1649, and the Fifth part of the Discours de la methode). In Lettre au Marquis de Newcastle (1646), Descartes says:

Car bien que Montaigne et Charron aient dit qu'il y a plus de différence d'homme à homme, que d'homme à bête, il ne s'est toutefois jamais trouvé aucune bête si parfaite qu'elle ait usé de quelque signe pour faire entendre à d'autres animaux quelque chose qui n'eût point de rapport à ses passions; et il n'y a point d'homme si imparfait, qu'il nen use; en sorte que ceux qui sont sourds et muets, inventent des signes particuliers, par lesquels ils expriment leurs pensées. Ce qui me semble un très fort argument pour prouver que ce qui fait que des bêtes ne parlent point comme nous, est quelles nont aucune pensée, et non point que les organes leur manquent. Et on ne peut dire qu'elles parlent entre elles, mais que nous ne les entendons pas; car, comme les chiens et quelques autres animaux nous expriment leurs passions, ils nous exprimeraient aussi bien leurs pensées, s'ils en avaient. ${ }^{4}$

But Descartes was more radical than Aristotle and the Schoolmen. For him, animals do not have a soul. Distinguishing between vegetative, sensitive and rational souls requires a sort of organicism and a sort of Neoplatonic faith in the existence of a Great Chain of Being, while Descartes was rigorously mechanistic: animals are machines and even if they certainly express their passions, such as fear or joy, this does not depend on a sensitive soul. Animals feel pain, but in a nonreflective manner, with no possibility to be mediated through reason. An animal can feel pain, but it cannot think about its pain; it can sense it, but it cannot reflect on it. As Descartes says in the letter to Morus, "Que les chiens approuvent de la queue, ce sont là seulement des mouvements qui accompagnent les affections, et je

4 "For although Montaigne and Charron have said that there is more difference between one man and another than between a man and a brute, nevertheless there has never yet been found a brute so perfect that it has made use of a sign to inform other animals of something which had no relation to their passions; while there is no man so imperfect as not to use such signs; so that the deaf and dumb invent particular signs by which they express their thoughts, which seems to me a very strong argument to prove that the reason why brutes don't talk as we do is that they have no faculty of thought, and not at all that the organs for it are wanting. And it cannot be said that they talk among themselves, but we do not understand them; for, as dogs and other animals express to us their passions, they would express to us as well their thoughts, if they had them." Quoted from: Rosenthal, David M. (ed.) 2000. Materialism and the MindBody Problem. (2nd ed.) Indianapolis: Hackett Publishing Company, p. 22 (reprinted from: The Philosophy of Descartes. Selected and translated by Henry A. P. Torrey. New York: Henry Holt and Company, 1892, 281-284). 
pense qu'il faut soigneusement les distinguer du langage qui seul revèle la pensée latente dans les corps". ${ }^{5}$ In an animal, there is no intermediary between stimulus and response.

Descartes did not share the Aristotelian idea that soul is life, but rather maintained that life is like a fire in the heart. The heart pumps "animal spirits" to the brain, and from the brain, through the nerves, these spirits pass to muscles, thus causing the movement of limbs. An animal body is simply a mechanism. They are mere res extensa and not res cogitans.

It is curious that at the time the Cartesian argument was taken as the only way to save the immortality of human souls. In fact, animals not being immortal does not prove that humans are. Descartes was convinced in the immortality of human soul for religious reasons and simply admitted that one could not prove that God could not annihilate a soul, even though it was reasonable to suppose that, in being entirely distinct from body, a soul is not bound by nature to die with it (Descartes's letter to Mersenne, 1640). Moreover, it was possible to refute the idea that animals are immortal without assuming that they have no soul. In fact, Aquinas had already solved the question by saying - and this seems to me more modern than many present discussions on abortion or experiments on embryos - that the rational (and immortal) soul is introduced into the foetus by God only some months after the conception, and that embryos will not take part in the resurrection of flesh. Embryos are not immortal because they only have a sensitive and not a rational soul. And so, obviously, happens to be the case with animals.

Anyway, the discussions on Descartes's mechanistic and dualistic ideas ran through two centuries and interested people like Leibniz, Locke, Cudworth, More, Shaftesbury, Cordemoy, Fontenelle, Bayle, Buffon, Rousseau, and others.

The dominant question was the one of the animal soul and of its alleged immortality; the linguistic problem was only - following Aristotle and Descartes a way to prove the absence of a soul. The main argument was obviously that animals are incapable of expressing thoughts, incapable of entertaining abstract ideas. As a supplementary argument, since animals could express neither thoughts nor abstract and general ideas, they were unable to think of God. As Cimatti has recently repeated, it seems difficult to think that a polyp can rise any question about the existence of God. ${ }^{6}$ But, as we shall see, it was not necessary to be a mechanist - or to deny that animals have a language - in order to establish that they were not religious beings.

5 "If the dogs show approval with their tail, these are only movements that accompany the affections, and I think that we must carefully distinguish them from the language which alone reveals the latent thought in the bodies."

6 Reference to Cimatti, Felice 2002. La mente silenziosa: Come pensano gli animali non umani. 
There were, however, other moral and theological reasons to be a mechanist and a dualist. First of all, there was a discussion concerning cruelty against animals, from meat eating to hunting and vivisection. By assuming that animals were machines men would not feel guilty for killing animals. Secondly, there was a sort of defence against the so-called "superstitions of Pythagoras" concerning the transmigration of souls. Souls cannot transmigrate into animals if animals have no soul. Obviously this did not eliminate the question whether human souls can transmigrate into other human bodies and the Cartesian dualism, as far as I know, gave no answer to this question.

The polemics about mechanism and dualism flared up very early. For instance, in 1678, in Le Discours à Madame de La Sablière, La Fontaine shares the opinions of Gassendi, who advocated the existence of a sensitive soul in animals. But probably the first author to deal with these arguments juxtaposing the different views was a certain Father Pardies who in 1672 wrote a Discours de la connaissance des bestes. Pardies, even admitting that animals do not speak as we do, says that, since humans have unconscious thoughts (a topic that had started to be discussed in the philosophical milieu at that time) and many of our behaviours - like breathing, walking and even playing an instrument by a sort of a natural habit - do not depend on voluntary and conscious decisions, the same can hold for animals. Thought is not required in order to speak, but only in order to decide to speak. God can have put in the animal organism a natural disposition to speak.

Pardies opens an interesting discussion on a phenomenon that was already observed by Augustine and that would also be discussed by further authors: if we cut a worm in several parts, we would realize that each part continues to live and to move. This would be proof that an animal soul, if any, is not a unique principle, as is the case with the human soul. It is only a matter of animal spirits, and animal spirits were admitted even by mechanists. Yet it had been ascertained that similar phenomena can occur also in men, as when a decapitated head continues to make grimaces for a while. Moreover, it is certain that animals are unable to form syllogisms, but it is also true that they recognize objects and know which ones are good or bad for them, and are able to behave according to a purpose. To deny that these are not operations depending on a soul would mean that we can even deny the existence of a human soul.

Humans certainly have the property of commanding their actions, but there are many actions that they perform instinctively. There certainly is a difference between sensitive and spiritual cognition: beasts have only sensitive cognition, deprived of a further reflection. But this happens with human beings too, since we can perceive many things without paying attention to them and without reflecting on them, as when we are reading a book and reflecting on the sense of the words, 
but perceive the single letters we read without any reflection. All this means that similar principles are at work both in animals and humans. In a scholastic vein, Pardies assumes that all these operations request a soul as a substantial form and that consequently animals cannot be mere machines.

A few years later the arguments of Pardies were criticized by a mechanist, Antoine Dilly, in his Traité de l'âme et de la connaissance des bêtes (1676), but Pardies had outlined an argument that would be drawn on by further authors, and which depended, probably in a still obscure way, on the assumption of a Great Chain of Being and on a sort of pre-evolutionistic principle of the continuity of life. We can speak of souls of animals, provided that we assume that life is a sort of continuum, evolving without interruption and without any fixed borderline between res extensa and res cogitans, by degrees of increasing complication.

That was certainly the position taken by the protestant David Boullier in his Essai philosophique sur l'âme des bêtes, in 1728. Boullier's book is very well argued with many precise references to the contemporary literature on this topic. More than against Cartesians, Boullier is debating against the Libertines of the 17 th century, who were decidedly materialists. He is arguing against mechanism because, proceeding from this principle, it cannot but depend on a denial of the immortality of human souls.

An inquiry into the physical nature of animals proves that their organism (so similar to the human one) is conceived in order to host a soul. Animals do not only have sensations, but also intelligence and free will. Suppose we have beaten our dog because he ate a partridge instead of bringing it to us; after that the dog will certainly refrain from eating his further prey - even if the partridges are not the same as the first one. This means that the dog is able to shift from the particular perception of that partridge to the general idea of partridge. This experience does not only prove that dogs are capable of general ideas, but also that they are able to foresee a future evil and avoid it by an act of free will.

Boullier admits that the operations of a soul are determined by the perfection of the body that hosts it. Therefore souls are a genre and the species of human souls is different from the many species of animal souls. More explicitly than in Pardies, this is a matter of a gradual development. The animal soul cannot conceive of God, but to say that it belongs to a lower stage of development than ours does not mean to deny that it is a soul.

Here, Boullier uses an extraordinary argument: animals have perceptions, but while ours are clear, theirs are vague. As far as I remember it was only in 1739 that Baumgarten spoke of a cognitio sensitiva, a sort of primary form of knowledge, less clear than rational knowledge but in any case very important for human life, since it explains our aesthetic experience. Boullier does not quote any German 
sources, but only French authors; in spite of this, in order to define a kind of vague perceptions, he gives as the example of our perception not a single musical sound, but a complex chord, where humans perceive different sounds without distinguishing them, yet realizing that there are many. I am astonished by the fact that Boullier was probably the first to say that animals think aesthetically, in other terms, that - although they are unable to make syllogisms and to ask whether there is a God or not - they have a sort of artistic thought. Boullier says that "létat le plus imparfait de lâme humaine représente assez bien la nature de celle des brutes".

In many places, Boullier reminds his readers that even in human beings there are stages of development, that the soul of a child is less developed than that of an adult, and that (let us forgive him his politically incorrect views) there is less difference between an ape and an African than between an African et "un bel esprit Européen". ${ }^{8}$ Undoubtedly, he expressed the idea of graduality of development that not only occurs within the life span of a single individual, but also between the lower and the highest species.

In the same vein, Condillac, in his Traité des animaux (1755), says that animals are not machines because they are able to compare all the sensations they receive, and are able to judge and to remember. Obviously, animals think according to their needs, and since every animal species has different needs, the members of each species have a different way of knowing, of satisfying their needs, and of communicating their purposes to each other. Every species of animals has a language, even though proportioned to the needs of the species. Signs of their thoughts are mainly inarticulate cries and bodily actions, but in order to share the same body language they must have the same body features, that is, they must belong to the same species. Animals such as dogs understand even our words insofar as they associate some order and request with a given sound, and they can understand these because they correspond to their own behaviour. As a conclusion, animals do not speak like humans, but the difference is in degree of complexity, "du plus au moins".

For these reasons it has been suggested that Condillac in some ways anticipated the transformism of Lamarck and the evolutionism of Darwin. Maybe it is too much, but it seems to me that it is in this cultural milieu that the idea of a biological continuity appeared.

Boullier's views were largely used by the Abbé Yonne in the article of the Encyclopedie on "L'Âme des bêtes", but this article also refers to another author

\footnotetext{
7 "The most imperfect state of the human soul represents quite well the nature of that of the beast".

8 "A beautiful European spirit".
} 
who spurred more reactions than Boullier. In 1739, Guillaume Hyacinthe Bougeant published an Amusement Philosophique sur les Langages des Bêtes. He was a Jesuit, his ideas could not have pleased his Order, he had, in fact, many troubles and was even obliged to write a retraction of his positions in a letter to the Abbé Savalette. The story is very confusing as there were at least two editions (Amsterdam and Paris) of Bougeant's book published in the same year, and there are copies of both editions with and without the letter. Moreover, the letter to Savalette is dated April 1739 , preceding the publication of the book. This means that Bougeant did retract his position, but published his retraction together with the first edition of his book. Perfect for a Jesuit, especially if we consider that the title of the book (not by chance addressed to a Lady and not to the scientific community) speaks of an "Amusement", and thus Bougeant seems to speak tongue in cheek. However, his book was taken seriously by many other authors.

Bougeant maintains that beasts manifest intelligent behaviour, that they do speak and understand each other and that they communicate with us: "You have a Bitch, which you love, and which you think yourself reciprocally loved by. Now I challenge all the Cartesians in the World to persuade you that your Bitch is a mere Machine".

If animals are like us, should they have a Paradise and a Hell reserved for them? Bougeant's answer is rather provocative: beasts are devils, put in animals' bodies in order to carry their hell with them everywhere. This also explains why they are so brutish (cats are unreliable, lions cruel, insects eat one another, and so on), and why they are condemned to suffer human cruelty. Moreover, Bougeant accepts the idea of a metempsychosis, which must be denied for men: to continue their earthly hell, devils - after the death of their animal host - migrate into other animal bodies.

If this argument sounds preposterous, Bougeant's accounts of animal language are less so. Animals could not establish a society or even a couple, supposed to nurture their young, if they had no means to communicate and to teach each other - and he provides many examples of animal communities that can live only on the grounds of a communicative agreement, thus establishing roles and functions for every member of the group, as otherwise they would be in the same situation as men after the confusion of languages in the times of the Babel Tower. After having criticized the dubious notion of instinct (since we have poor ideas about our own instincts, we know much less about animal instinct), Bougeant shows how animals have linguistic skills analogous to those of mutes who substitute words with cries, gestures, looks and postures. Bougeant, too, assumes that animals communicate according to their specific needs, more limited than ours. That is why animals are more laconic than humans (some of them do not say 
more than three or four words per day) and communicate only what is essential to their individual and social survival. In this sense they never lie, "non pas même en amour" - like our peasants and the savages of America.

Bougeant tells his Lady that it would be difficult to establish a dictionary for the language of every animal species, also because some of them, such as fishes and spiders, emit sounds that we cannot hear. But he seems convinced that every species has its own sounds and in this sense he goes beyond those who only spoke of a mere gestural and behavioural language. He devotes some interesting, even though very naïve, discussions to birds' language (birds do not sing, they do speak) and makes a careful difference between a complex tongue, in the sense of human langue, and an ability in terms of language, but does not show any virtue of semiotic observation.

John Hildrop, in his Free Thoughts upon the Brute-Creation (1742-1743) criticized the idea that animals were devils: animals insofar as they were dominated by man, were simply involved in the original sin. But, since they do have a soul and existed in the Garden of Eden, they are worthy of immortality.

William Smellie (Philosophy of Natural History, 1790-1799) insisted on the social life of animals, saying that beavers show better republican attitudes than men. Animals have societies, intelligence, and a great ability to imitate. Brutes are simply at an inferior degree of perfection in comparison with humans, they even look smarter than us in certain affairs.

If Boullier and Bougeant were following a spiritualistic approach, the same results were reached a few years later by a materialist like La Mettrie. La Mettrie, who was a physician, insisted on the similarities in anatomy and physiological functions of both animals and men. In Histoire naturelle de l'âme (1745), La Mettrie first considered Descartes' view that animals are pure machines "an absurd system", "a ridiculous opinion" because this position excludes the faculty of sensation. For him, sensation was one of the attributes of matter, along with extension and moving force, although it only appears in organic bodies, and all the intellectual faculties, both in man and animal, can be explained in terms of sensations.

In L'homme machine (1748) he turns the Cartesian argument upside down. Not only animals, but also men are machines: nature has used the same matter to form man and animal, "only varying [the amount of] leaven". If the crucial argument for the difference between man and animal was linguistic competence, La Mettrie says that animals have an affective language; they certainly cannot use words, but perform excellent pantomimes. They use a smaller amount of signs than humans, but it is possible to teach an ape a human language. La Mettrie is aware of the inadequacy of apes' vocal apparatus, but says that, if duly trained, an ape can correlate sounds with motions of the brain. We are made human by education and 
thus it not impossible to educate animals: "A geometrician has learned to perform the most difficult demonstrations and calculations as a monkey has learned to take its little hat off and on".

Thus, the difference between the human and the animal languages is merely quantitative. Humans became intelligent because nature made them more helpless than other animals, and thus they were obliged to develop their intellectual abilities in order to survive: "Having infinitely more needs, it was necessary that man had infinitely more esprit".

Rousseau spoke of man's fall from innocence into history and society in the Second Discourse (1755); there he also suggested that orangutans were men in the state of nature. Lord Monboddo, in Of the Origin and Progress of Language (1773-1792) and Ancient Metaphysics (1779-1799), argued that orangutans were human, and that humanity was independent of the use of language. Monboddo did not consider orangutans as animals, but contributed to the blurring of the line between humans and the higher primates.

I shall only mention another aspect of this debate, which does not directly concern language, but rather our duties toward animals. For instance, Richard Dean says in An Essay on the Future Life of Brutes (1768) that the suffering of animals is a consequence of man's sin, but with man's redemption the rest of nature will be redeemed as well. Since they have an immortal soul, animals cannot be taken as a mere instrument of human pleasure. Hovever, like Charles Bonnet in his Palingénésie Philosophique published in 1769, Dean assumes that as much as human reason exceeds brute faculties so will human bliss exceed brute bliss in their life after death.

On the contrary, Humphry Primatt in A Dissertation on the Duty of Mercy and Sin of Cruelty to Brute Animals (1776) maintains that insofar as "we have no authority to declare, and no testimony from heaven to assure us, that there is a state of recompense for suffering Brutality, we will suppose there is none; and from this very supposition, we rationally infer that cruelty to a brute is injury irreparable". While human suffering can be "overbalanced in a future and happy state, [...] what hope, what glimpse of recompense hereafter awaiteth the afflicted brute?"

Starting from different positions, and on Rousseauian grounds, John Oswald argues in The Cry of Nature (1791) against meat eaters, the "sons of science", vivisectionists and animal torturers, plunging "into her maternal bosom [...] the butcher knife". He denies that animals were created to submit to humans by "decrees of heaven". In the beginning men lived in a state of nature where "in the bonds of society with man, the milder and more congenial animals united". Only later, through the development of science and technology, did exploitative relationships increase and humans started to consider animals as mere objects: 
"The fate of the animal world has followed the progress of man from his sylvan state to that of civilization".

Let me stop this absolutely incomplete survey. Today, we either argue in favour of animal life (and this is a moral and political attitude, independent of the fact whether animals have a soul or not, and whether they speak or not), or we conduct research on animal language (and this is a semiotic approach, independent of the fact that we eat fish even when we recognize that fishes communicate with each other). Perhaps the debate of the 17 th and 18 th centuries was more organic and well balanced.

Let me conclude with three quotations. Two come from the Journal of Jules Renard (nomen omen): "Âme, c'est bien là le mot qui a fait dire le plus de bêtises. Quand on pense qu'au XVIIe siècle des gens sensés, de par Descartes, refusaient une âme aux animaux!"9 (18 January, 1889). "Notre âme est immortelle, pourquoi? Et pourquoi pas celle des bêtes? Quand les deux flammes sont éteintes, quelle différence y a-t-il entre la flamme d'une pauvre chandelle et celle d'une belle lampe au bec compliqué, haute sur tige, et dont l'abat-jour sécarte comme une jupe?"10 (30 May, 1900).

The third quotation comes from $\grave{A}$ se tordre (1891) by Alphonse Allais: "Les bêtes ont-elles une âme? Pourquoi n'en auraient-elles pas? J'ai rencontré, dans la vie, une quantité considérable d'hommes, dont quelques femmes, bêtes comme des oies, et plusieurs animaux pas beaucoup plus idiots que bien des électeurs"11.

\section{7th- and 18th-century sources ${ }^{12}$}

1646 Descartes, René. Lettre au Marquis de Newcastle, 23 Nov.; Letter to Henry More.

1649 Descartes. René. Discours de la methode, V.

1662 De la Chambre, Marin Cureau. Traité de la connoissance des animaux, où tout ce qui a esté dit, pour, \& contre le raisonnement des bestes, est examiné. Paris.

9 "Soul, that's the word that has made us say the most of nonsense [lit. 'foolishness']. When one just thinks that in the seventeenth century sensible people, influenced by Descartes, refused a soul to animals!"

10 "Our soul is immortal, why? And why not that of brutes? When the two flames are extinguished, what is the difference between the flame of a poor candle and that of a beautiful lamp with a complicated beak, high on a stem, and whose shade spreads like a skirt?"

11 "Do beasts have a soul? Why wouldn't they? I have met in my life a considerable number of humans, including some women, stupid like geese, and several animals not much more stupid than many voters."

12 The reference lists are Eco's, slightly edited, but with no entries added. 
1672 Pardies, P. Ignace Gaston. Discours de la connoissance des bestes. Paris: Chez Sebastien Mabre-Cramoisy, Imprimear du Roy, Rue Saint Jacques, aux Cicognes.

1676 Dilly, Antoine. Traité de lầme et de la connaissance des bêtes.

1678 La Fontaine, Jean de. Discours à madame de la Sablière (sur l'âme des animaux).

1690 Locke, John. Essay on Human Understanding II, xi, 10.

1790-1799 Smellie, William. Philosophy of Natural History.

1728 Boullier, David. Essai philosophique sur l'âme des bêtes, où l'on traite de son existence \& de sa nature et où l’on mêle par occasion diverses réflexions sur la nature de la liberté, sur celle de nos sensations, sur l'union de l'âme \& du corps, sur l'immortalité de lâme, \& et où l'on réfute diverses objections de Monsieur Bayle.

1737 Abbé Macy. Traité de lầme des bêtes.

1739 Bougeant, Huillaume H. Amusement philosophique sur le langage des bestes.

1739 Daniel, Gabriel. Voyage du Monde de M. Descartes.

1742 Hildrop, John. Free Thoughts upon the Brute-Creation.

1745 La Mettrie, Julien Offray. Histoire naturelle de l'âme.

1748 La Mettrie, Julien Offray. L'homme machine.

1749 Guer, Jean-Antoine. Histoire critique de l'âme des bêtes, contenant les sentiments des philosophes anciens \& ceux des modernes sur cette matière.

1751 Labbé Yvon. Âme des bêtes, L’Encyclopédie.

1755 Étienne Bonnot, abbé de Condillac. Traité des animaux.

1757 Jenyns Soame. A Free Enquiry into the Nature and Origin of Evil.

1789 Bentham, Jeremy. An Introduction to the Principles of Morals and Legislation.

\section{References}

Drozdek, Adam 2001. Descartes' Turing test. Epistemologia 24(1): 5-30.

Eco, Umberto; Lambertini, Roberto; Marmo, Costantino; Tabarroni, Andrea 1989. On animal language in the medieval classification of signs. In: Eco, Umberto; Marmo, Costantino (eds.), On the Medieval Theory of Signs. (Foundations of Semiotics 21.) Amsterdam: John Benjamins Publishing Company, 3-41.

Ferrater Mora, José 1979. Alma de los brutos. In: Diccionario de filosofía. Vol 1. Madrid: Alianza Editorial, 109-113.

Garrett, Aaron 2000. Animal Rights and Souls in the Eighteenth Century. Vol 1. Bristol: Thoemmes, v-xxiv. 


\section{Язык животных до Себеока}

Публикация речи Умберто Эко в Сан Марино на симпозиуме в честь Томаса Себеока (1920-2001) в 2002 году.

\section{Loomade keel Sebeoki eel}

Publitseeritakse Umberto Eco ettekande tekst, mille ta esitas Thomas A. Sebeoki (1920-2001) mälestuseks korraldatud sümpoosionil San Marinos aastal 2002. 